\title{
iorhs
}

\section{Negative Prefixes In English And Their Equivalents In Serbian Within Computer Register}

\author{
Sladjana Živković \\ College of Applied Technical Sciences, Niš, Serbia
}

\begin{abstract}
This paper deals with the analysis of English prefixes expressing negation and the equivalents in the Serbian language within computer register. Since a wide range of new words appears in the process of new technologies development, it is essential to study and analyze the way they were formed.

Examining negative prefixes in computer register in English, we have found five of them: $d e$ , dis-, in-, non-, un. In terms of the Serbian equivalents the research has shown that they are the following: de-, dis-, iz-, ne-, po-, pre-, raz-. It has been descovered that the prefixes $d e-$ and dis- (in one of the examples) are translated into Serbian by their international analogues. In the case of the in- and non-prefixes, the research shows that it has a direct equivalent and it is the prefix ne-. Findings also show that he English prefix un- has more than one equivalent in Serbian, surprisingly, there are four of them: ne-, po-, iz- and raz-.

The analysis implies etymology (focus on origin), semantics (including meaning) and morphology (including derivational patterns of one-word terms).
\end{abstract}

Key words: negative prefixes, computer register, etymology, semantics, morphology

\section{Introduction}

New technologies, as the computer technology is, require new terminology. Since a wide range of new words appears in the process of new technologies development, it is essential to study and analyze the way they were formed. It should be noted that negative prefixes have an important role in word formation in the English language, as well as in Serbian.

It is important to note that we expected more differences of prefixes in two analysed languages. Examining negative prefixes in computer register in English, we have found five of them: de-, dis-, in-, non-, un. On the other hand, the research has shown that the equivalents in Serbian are the following: de-, dis-, iz-, ne-, po-, pre-, raz--

In addition, they can be classified according to the origin, where in English the prefix un- is the only native prefix, whereas, in Serbian $i z_{-}^{-}, n e-$, po-, pre-, raz . are of native origin, and $d e-$ and dis- are prefixes of foreign origin.

Morphologically speaking, these prefixes in the English language form verbs (de-, dis-, un-), nouns (in-, non-, un-) and adjectives (in-, non-, un-). In Serbian the situation is the following: prefixes iz-, ne-, po-, pre-, raz form verbs, ne- prefix forms nouns, and the same is with forming adjectives. 


\section{icrhs}

4th International Conference On Research In HUMANITIES \& SOCIAL SCIENCES

Thus, in the following we look in more detail at negative prefixes, their meaning, origin and derivational patterns. The prefixes are listed in alphabetical order.

\section{The analysis of negative prefixes}

1.Prefix de-

Let us begin by examining the prefix $d e$-. From the point of view of etymology, this prefix is of Latin origin. As noted by Quirk (1985), the prefix is called reversative, because it means 'reversating the process described by the original words' as in the example of the verb demodulate which means 'to reverse modulate'.

Regarding the prefix de-, Stekauer and Lieber (2005) conclude that it is typically characterized as privative, expressing 'lacking, not having, or preventing from having'. Take, for example, the verb demagnetize which means 'not having magnetic properties'.

Dealing with the same prefix, Jespersen (1970) concludes that it is a verbal one, as it is confirmed in the case of computer register. Apparently, from the examples we have found out, this prefix attaches verbs in ize- and ate- (except decode). Here are a few examples:

deactivate - deaktivirati

decentralize - decentralizovati

decode - dekodirati

demodulate - demodulisati

demagnetize - demagnetisati

denormalize - denormalizovati

As it can be seen from the examples above, the prefix $d e$ - is appeared in the Serbian language in all these examples. In other words, it means that there is no a direct equivalent in Serbian.

Klajn (2002) states out that it is primarily a verbal prefix, so, a great number of nouns can be considered derivatives from verbs. He also points out that the characteristic of this prefix is, that it attaches to the foreign origin bases, as it is evident from the above mentioned examples.

\section{Prefix dis-}

Next, let us discuss the prefix dis-. Etymologically, the prefix is of Latin origin, just like the previous one. According to Zandvoort (1969), this prefix may express negative meaning, or the reversal of an action. Take, for example, the verb disassemble, and it means 'to reverse the process of assembly'; whereas, the verb disconnect is 'the opposite of connect'.

As is evident from all the examples here, it is a verbal prefix. Now, here are some verbs with the prefix dis-:

disassemble - disasemblirati

disconnect - prekidati

dispatch - rasporediti

displace - premeštati

It is interesting to notice that this prefix has three equivalents in Serbian. They are: dis-, pre-, raz-. With the exception of the prefix dis-, as an international analogue, the others are of native origin.

According to Klajn (2002) dis- is the verbal prefix with privative meaning, as in disasemblirati ('preventing from assemble'). 


\section{iorhs}

\section{4th International Conference On Research In}

HUMANITIES \& SOCIAL SCIENCES

The other one is the prefix raz-, and it is one of the most productive prefixes in the Serbian language. It is interesting to notice that this prefix is added to a prefixed verb $(r a s+p o+$ rediti). It is worth mentioning that double prefixation is a characteristic of the Serbian language. The meaning of the verb rasporediti is 'motion in different directions'.

The prefix pre- is also appeared here, and it is a productive verbal prefix in Serbian, with diversity in meaning. In prekidati it has the meaning of interrupting, and in premestati it means 'motion from one place to another'.

\section{Prefix in-}

Let us explore the next prefix, it is the prefix in-. From the etymologycal point of view, it is of Latin origin. Paying attention to this prefix, Katamba (1993) notes that it is prefixed to adjectives. When considering the same prefix, Stekauer and Lieber (2005) notice that it is productive not only on adjectives, but on nouns as well. As noted by the same authors, the meaning of the prefix is negative both on nouns and adjectives. For example, the noun inaccuracy describes 'lack of accuracy, not accuracy'; the adjective inefficient means 'not producing desired results'.

Let us look at the examples of nouns formed by the prefix in-:

inaccuracy - netačnost

incoherence - nekoherentnost

inefficiency - neefikasnost

instability - nestabilnost

And now, here are a few examples of adjectives formed by the same prefix:

incompatible - nekompatibilan

inefficient - neefikasan

infrequent - nefrekventan

incoherent - nekoherentan

irregular - neregularan

As we can see from the above mentioned examples, the direct equivalent in Serbian is the native prefix $n e-$. According to Klajn (2002), this prefix is highly productive with nouns, as well as with adjectives, and it has the opposite meaning to the original noun or adjective.

\section{Prefix non-}

In dealing with the properties of the prefix non-, first, we can say that it is of Latin origin. As noted by Jespersen (1970), the prefix attaches to nouns and adjectives, but it rarely attaches to verbs, and it is the same in computer register.

Its basic meaning is 'not'. Stekauer and Lieber (2005) point out that non- is quite productive on nouns. They say that the meaning of this prefix is 'not have the qualities or characterictics referred to'. For example, nonlinearity is 'the state of being nonlinear, or not have the characteristic of being linear'.

The following are the examples of nouns with the prefix non-:

nondeformation - neizobličenost

nonlinearity - nelinearnost

nonredundancy - neredundantnost

nonuniformity - neravnomernost 


\section{Eorhs}

\section{4th International Conference On Research In}

HUMANITIES \& SOCIAL SCIENCES

Stekauer and Lieber (2005: 391) mention that non- attaches quite freely to adjectives. Nowadays, non- can be prefixed to almost any adjective (Marchand 1960). For example, nonmagnetic is 'not capable of being magnetic'.

Here are some more examples:

nonadaptive - neadaptivan

nonelectric - neelektričan

nonerasable - neizbrisiv

nonflexible - nefleksibilan

nonprogrammable - neprogramabilan

nonsynchronous - nesinhron

Within our contrastive analyses, we have found out that the equivalent in Serbian is the prefix $n e$ - in all the analysed examples with the general meaning 'not'. For example, the adjective nonelectric means 'not electric, not capable of conducting electricity'.

\section{Prefix un-}

Let us now turn to the last prefix, it is the prefix un-. Unlike all other mentioned English prefixes here, it is the only one of native origin.

As noted by Katamba (1993), it is prefixed to adjectives when it means 'negative', and to verbs when it means 'reversative'. Similarly, Stekauer and Lieber (2005) state out that the meaning of this prefix is negative on nouns and adjectives, and reversative when attaches to verbs. For example, the noun unavailability means 'the quality or state of not being available'; the adjective unbaffered is 'without a hardware or software buffer'; the verb undo means 'reverse an action or its effect'.

Plag (2003) notes that this prefix attaches to verbs, but rarely to nouns. The same author discusses the meaning, and concludes that it has reversative or privative meaning. Within the literature on prefixation, the extensive research of the prefix un-can be found in Jespersen (1970), and he considers that it is the adjectival, not the verbal prefix. On the other hand, in computer register the prefix attaches to all 3 categories of base: nouns, adjectives, verbs.

Take a look at nouns with the prefix $u n-$ :

unavailability - neraspoloživost

uncompatibility - nekompatibilnost

Here are some examples of adjectives formed by the prefix un-:

unavailable - neraspoloživ

unbuffered - nebaferovan

undisturbed - neometan

unclocked - nesinhronizovan

uncompatible - nekompatibilan

unmodulated - nemodulisan

Let us see some examples of verbs with the prefix un-:

undelete - poništiti

unload - isprazniti

unpack - raspakovati

Things are quite different with Serbian prefixed translation equivalents. From the examples presented above, it is evident that there are four direct equivalents in Serbian: ne-, po-, iz-, raz-. 


\section{icrhs}

\section{4th International Conference On Research In}

HUMANITIES \& SOCIAL SCIENCES

The prefix $n e$ - has been already discussed, and it has the general meaning 'not'. Take a look at some examples here. The noun unavailability means 'the quality of not being available'; the adjective unbuffered means 'without a buffer, i.e. that operates without a hardware or software buffer'; and the meaning of the verb undelete is 'not delete'.

The prefix po- is interesting to describe because of its diversity in meaning. As Klajn points out (2002), this prefix is one of the most productive verbal prefixes in the Serbian language. In poništiti this prefix has reversative meaning, it means 'reverse an action or its effect'.

From the above mentioned examples, it can be seen that there is another prefix, it is the prefix $i z-$, very productive verbal prefix, with diversity in meaning. The verb isprazniti has the meaning 'to remove the load'.

The prefix raz- has been previously discussed, so, here, the focus is on the meaning of the verb raspakovati, which means 'remove from its packing'.

And now, let us take a look at the data from the Tables.

Table 1. provides information about the number of English negative prefixes in computer register on one side, and their prefixed translation equivalents in Serbian on the other side. As the Table 1. shows there are five prefixes in English which reflect negation, whereas, in Serbian there appears dis-, pre-, raz- for English dis-, and ne-, po-, iz-, raz- for English un-.

Table 1. English prefixes and Serbian equivalents

\begin{tabular}{|l|l|}
\hline English prefixes & Equivalents in Serbian \\
\hline de- & de- \\
\hline dis- & dis-, pre-, raz- \\
\hline in- & ne- \\
\hline non- & ne- \\
\hline un- & ne-, po-, iz-, raz- \\
\hline
\end{tabular}

With regard to morphology, each of these prefixes attaches to different categories of base as the Table 2. below illustrates.

Table 2a. English prefixes / Categories of base: nouns, adjectives, verbs

\begin{tabular}{|l|l|l|l|}
\hline de- & & & verbs \\
\hline dis- & & & verbs \\
\hline in- & nouns & adjectives & \\
\hline non- & nouns & adjectives & \\
\hline un- & nouns & adjectives & verbs \\
\hline
\end{tabular}

Table 2b. Serbian prefixes / Categories of base: nouns, adjectives, verbs

\begin{tabular}{|l|l|l|l|}
\hline iz- & & & verbs \\
\hline ne- & nouns & adjectives & verbs \\
\hline po- & & & verbs \\
\hline pre- & & & verbs \\
\hline raz- & & & verbs \\
\hline
\end{tabular}

If we take a look at Table 3. it can be seen that it reviews the information about the origin of the examined negative prefixes in two languages, namely, English and Serbian. 


\section{Eorhs}

\section{4th International Conference On Research In}

HUMANITIES \& SOCIAL SCIENCES

It should be noted from Table 3. that the prefix un- is the only native negative prefix in the English language, whereas, the situation in Serbian is different.

Table 3. Prefixes and their origin

\begin{tabular}{|l|l|}
\hline $\begin{array}{l}\text { English } \\
\text { prefixes }\end{array}$ & origin \\
\hline de- & Latin \\
\hline dis- & Latin \\
\hline in- & Latin \\
\hline non- & Latin \\
\hline un- & English \\
\hline
\end{tabular}

\begin{tabular}{|l|l|}
\hline $\begin{array}{l}\text { Serbian } \\
\text { equivalents }\end{array}$ & origin \\
\hline iz- & Serbian \\
\hline ne- & Serbian \\
\hline po- & Serbian \\
\hline pre- & Serbian \\
\hline raz- & Serbian \\
\hline
\end{tabular}

\section{Conclusion}

This paper discusses negative prefixes in computer register in English, as well as their equivalents in the Serbian language in terms of morphology, semantics and etymology.

As it is evident from the research findings, the total number of English negative prefixes in computer register is five. They are the following: $d e-$, dis-, in-, non- and un-. Examining the same prefixes in mentioned register in the Serbian language, it has been found out that there are seven of them: de-, dis, iz-, ne-, po-, pre- and raz-. The prefixes de- and dis- (in one example) are translated into Serbian by their international analogues. The prefixes in- and non- have a direct equivalent, namely, it is the prefix ne-. The English prefix un- has more than one equivalent in Serbian, namely, there are four of them: $n e^{-}, p_{--}, i z-$ and $r a z-$.

It can be noted that, among the above mentioned examples, verbs predominate in English, as well as in Serbian. According to Stevanović (1986), the most numerous words with prefixes are verbs, while, nouns are so rare that they present no interest in word formation in the Serbian language. Similarly, Šipka (1998) notes that prefixation is more frequent with verbs.

However, there is a new tendency in the word formation which has become evident in computer register, that is, there are more and more nouns and adjectives with negative prefixes in English, and in Serbian as well.

Considering the origin of these prefixes, we can conclude that the most number of prefixes in English come from Latin. The fact is that Latin has influenced every modern language, including English. In addition, computer terminology uses words created by using prefixes, primarily, of Latin origin.

To sum up, this paper may serve as a basis for further investigations on contrastive analysis of English and Serbian negative prefixes in the field of computer register.

\section{References}

Glendinning E. and Glendinning N. 1995. English for Information Technology, Oxford: Oxford University Press.

Glendinning, E. and McEwan, EJ. 1999. Basic English for Computing, Oxford: OUP. 


\section{iorhs}

\section{4th International Conference On Research In}

HUMANITIES \& SOCIAL SCIENCES

Jespersen, O. 1970. A Modern English Grammar: On Historical Principles, London: George Allen \& Unwin Ltd.

Katamba, F. 1994. English Words, London: London Clays Ltd.

Klajn, I. 2002. Tvorba reči u savremenom srpskom jeziku, Prvi deo - slaganje i prefiksacija, Beograd: Zavod za udžbenike i nastavna sredstva.

Klajn, I., Šipka, M. (2006) Veliki rečnik stranih reči i izraza, Prometej, Novi Sad.

Longman Dictionary of Contemporary English, (1988) Longman, London.

Marchand, H. 1960. The Categories and Types of Present-Day English Word-Formation, Weisbaden: Otto Harasowitz.

Plag, I. 2003. Word-Formation in English, United Kingdom: Cambridge University Press.

Quirk, R..,Greenbaum, S., Leech, G. and Svartvik, J. 1985. A Comprehensive Grammar of the English Language, London: Longman.

Stageberg, N. 1971. An Introductory English Grammar, New York: Holt, Rinehart and Winston.

Stevanović M. 1986. Savremeni srpskohrvatski jezik, Beograd: Naučna knjiga.

Šipka, D. 2005. Glosar tvorbenih formanata, Beograd: Alma.

Štekauer, P.and Lieber, R. 2005. A Handbook of Word-Formation, Netherlands: Springer.

Terminološki rečnik (informatika), (1998) Gradjevinska knjiga, Beograd.

Tošić, Ž., Tošić, T. (1998) Rečnik računarske tehnike i informatike, Poslovni sistem „Grmeč,, Beograd.

Webster's Third New International Dictionary (1993), Merriam-Webster, Incorporated, Springfield, Mass, USA.

Zandvoort, R.W. 1969. A Handbook of English Grammar, London: Longmans, Green and Co. Ltd. 